\title{
Frustração ou Fraude à Licitação: Aspectos Penais e de Improbidade Administrativa
}

\author{
José Antonio Remedio \\ Doutor em Direito do Estado pela Pontifícia Universidade Católica de São Paulo \\ (PUCSP). Professor de Graduação e Pós-graduação (Mestrado) em Direito da \\ UNIMEP e Professor de Graduação em Direito da UNASP. E-mail: \\ jaremedio@yahoo.com.br
}

\section{Luiz Felipe Gomes de Macedo Maganin}

Mestrando em Direito pela Universidade Metodista de Piracicaba. E-mail: maganin@staadvogados.com.br

\begin{abstract}
Resumo: A pesquisa tem por objetivo geral dispor sobre fraude à licitação e improbidade administrativa. Como objetivo específico, busca a pesquisa analisar as consequências político-administrativas e penais decorrentes dos atos que importem na frustação ou fraude da licitude de processo licitatório, com ênfase ao elemento subjetivo do ato de improbidade previsto no inciso VIII do artigo 10 da Lei 8.249/92 e do crime de licitação contemplado no artigo 90 da Lei 8.666/93. O método adotado é o dedutivo, com base na legislação, doutrina e jurisprudência. A regra básica para a contratação de terceiras pessoas pela Administração Pública para a execução de obras, serviços, compras e alienações é a obrigatoriedade de realização de prévio procedimento licitatório, no qual sejam respeitadas a isonomia entre os participantes e a lisura do certame. Embora a frustração ou a fraude ao caráter competitivo da licitação ostente consequências tanto na seara políticoadministrativa quanto na criminal, tem-se que não há correlação direta entre os atos de improbidade lesivos ao erário e o crime de frustração ou fraude à licitação. Tem-se, também, que a incidência cumulativa nas esferas político-administrativa e penal está restrita ao caso em que o ato ilícito esteja revestido pelo elemento subjetivo dolo e desde que exista prejuízo concreto ao erário nas duas hipóteses.
\end{abstract}

Palavras-chave: Fraude à Licitação. Frustração à Licitação. Improbidade Administrativa. Licitação Fraudulenta. Elemento Subjetivo.

\section{UNIVERSIDADE FEDERAL DA PARAÍBA}




\section{Frustração ou Fraude à Licitação: Aspectos Penais e de Improbidade Administrativa}

José Antonio Remedio

Luiz Felipe Gomes de Macedo Maganin

\section{INTRODUÇÃO}

O Estado moderno identifica-se como uma das mais complexas formas de sociedade criadas pelo homem, havendo, inclusive, grande divergência doutrinária a respeito de suas notas características e de seus elementos essenciais (REMEDIO, 2018, p. $51)$.

A figura do Estado-Administração, com suas entidades, órgãos e agentes públicos, surge para executar e fiscalizar, direta ou indiretamente, "as atividades destinadas a satisfazer as necessidades coletivas essenciais, como a segurança pública e as comunicações, bem como as necessidades coletivas instrumentais, a exemplo do fornecimento de água, energia elétrica e outras" (PRADO; CASTRO, 2015).

Objetivando a consecução de suas atividades e funções, em particular em relação à prestação de serviços públicos, ciente de sua insuficiência para atender direta e plenamente todas as demandas que lhe são afetas, a Administração também se utiliza da contratação de terceiras pessoas para sua execução ou realização (REMEDIO, 2018, p. 385). 
A regra básica para a contratação de terceiras pessoas pela Administração Pública, para a realização de obras, serviços, compras e alienações, é a realização de prévio procedimento licitatório, conforme preconizado no inciso XXI do art. 37 da Constituição Federal. No âmbito infraconstitucional, a licitação e os contratos administrativos são regidos em suas linhas básicas pela Lei Federal 8.666/93, conhecida como Lei Geral de Licitações, editada pela União, com base no art. 22, inciso XXVII da Lei Maior.

$\mathrm{Na}$ perspectiva da supremacia do interesse público sobre o privado e da prestação de serviços públicos essenciais à comunidade, "as atividades de gestão pública estão vulneráveis a intervenções que às vezes não atendem às necessidades coletivas, mas também acabam por transformar o aparato estatal em instrumento para satisfação de interesses privados", de forma que o interesse público que permeia as atividades da Administração Pública termina sendo relegado a um plano meramente simbólico (PRADO; CASTRO, 2015).

No âmbito público, o conceito de corrupção designa a apropriação de recursos públicos ou desvirtuamento de regras regentes do Estado. Trata-se de um desvio funcional. Afirmar que um indivíduo praticou corrupção significa dizer que sua conduta se desviou dos valores esperados e previstos no ordenamento jurídico para o exercício da função pública (SIMÃO, 2017, p. 39).

Os casos de corrupção ou improbidade administrativa são bastante amplos e diversificados no Brasil, envolvendo inúmeras pessoas e valores expressivos, muitos dos casos, inclusive, relacionados às licitações e contratações públicas.

Exemplificando, conforme divulgado por Débora Brito (2016), em balanço divulgado em dezembro de 2016, relativo à operação conhecida como Lava Jato, constatou-se que: foram iniciadas 17 investigações criminais e apresentadas 20 denúncias por crimes de corrupção ativa e passiva, lavagem de dinheiro e organização criminosa; aproximadamente $\mathrm{R} \$ 500$ milhões foram devolvidos à Petrobrás desde o início da operação; o valor das propinas pagas ultrapassa $\mathrm{R} \$ 6,4$ bilhões; o total dos prejuízos poderá 
ultrapassara casa de $\mathrm{R}$ \$40bilhões; houve 120 condenações criminais; na totalidade, mais de 1.200 anos de pena foram aplicados aos infratores na esfera criminal.

Assim, em se tratando de disfunções ocasionadas por desvios, privilégios e vantagens de qualquer natureza obtidas por agentes públicos ou terceiras pessoas em detrimento da Administração Pública, passa a incidir como consequência legal o aparato estatal sancionador.

A pesquisa tem por objetivo geral dispor sobre fraude à licitação e improbidade administrativa. Como objetivo específico, a pesquisa busca analisar as consequências político-administrativas e penais decorrentes de atos ilícitos que importem na frustação ou fraude do caráter competitivo dos procedimentos licitatórios, com enfoque no elemento subjetivo caracterizador do ato de improbidade administrativa lesivo ao erário previsto no inciso VIII do artigo 10 da Lei 8.249/92 e do crime de frustração ou fraude de licitação contemplado no artigo 90 da Lei 8.666/93.

Quanto à estrutura, inicialmente serão abordados aspectos gerais da improbidade administrativa na esfera políticoadministrativa, como seu conceito e fundamento. A seguir serão analisados os atos de improbidade administrativa lesivos ao erário, com ênfase aos atos que acarretam frustração ao processo licitatório previstos no inciso VIII do art. 10 da Lei 8.429/92. Em seguida serão enfocadas, sob a ótica penal, questões afetas ao crime de frustração ou fraude à licitação previsto no art. 90 da Lei 8.666/93. Por fim, será analisada a inter-relação existente entre a improbidade administrativa e o crime de licitação previstos respectivamente no inciso VIII do art. 10 da Lei de Improbidade Administrativa e art. 90 da Lei de Licitações, com especial ênfase ao elemento subjetivo das respectivas condutas.

O método adotado é o dedutivo, partindo-se de argumentos gerais, tidos como verdadeiros, para argumentos particulares, chegando-se assim às conclusões lógicas e formais. A base da pesquisa é a legislação, doutrina e jurisprudência. 
Frustração ou Fraude à Licitação: Aspectos Penais e de...

Tem-se, como hipótese, que, embora a frustração ou a fraude ao caráter competitivo da licitação ostente consequências tanto na seara político-administrativa quanto na esfera penal, não há uma correlação direta entre os atos ímprobos lesivos ao erário previstos no inciso VIII do art. 10 da Lei 8.429/92 e os crimes licitatórios contemplados no art. 90 da Lei 8.666/93, havendo incidência cumulativa das esferas político-administrativa e penal apenas na hipótese em que o ato ilícito esteja revestido pelo elemento subjetivo dolo, e desde que, no caso, exista prejuízo efetivo e concreto ao erário.

\section{IMPROBIDADE ADMINISTRATIVA E FRUSTRAÇÃO DO PROCESSO LICITATÓRIO}

A improbidade administrativa, enquanto infração políticoadministrativa, não possui conceito e contornos totalmente definidos, assim como seus fundamentos são extraídos de diversos âmbitos do Direito. A frustração do processo licitatório, desde que praticada dolosamente e acarrete prejuízo ao erário, insere-se como espécie de improbidade administrativa prevista expressamente no inciso VIII do art. 10 da Lei 8.429/92.

\subsection{CONCEITO E FUNDAMENTO DE IMPROBIDADE ADMINISTRATIVA}

A improbidade administrativa, embora não possua conceito legal prévia e totalmente definido, em linhas gerais está relacionada à imoralidade administrativa, à desonestidade, à má-gestão da coisa pública. 
O Estado Brasileiro tanto busca resguardar o patrimônio público relativamente aos agentes estatais que desrespeitam suas funções em benefício próprio ou alheio dissociado do interesse público, como não admite que sejam extirpados "direitos previstos constitucionalmente em prol dos administrados sem que sejam observadas todas as exigências preconizadas em lei para tanto", sob pena de se ultrapassar a linha da ética e moral protegidas pela probidade administrativa e pela razoabilidade (VEDOVATO; TELLES, 2017, p. 289-290).

A moralidade administrativa, enquanto princípio de obediência obrigatória pela administração pública direta e indireta de qualquer dos Poderes da União, dos Estados, do Distrito Federal e dos Municípios, constitui pressuposto de validade de todo e qualquer ato administrativo, nos termos do caput do art. 37 da Constituição Federal.

Maurice Hauriou (1926, p. 197), um dos pioneiros a definir a moralidade administrativa, não a vincula à moral comum, mas sim, à moral jurídica, entendida como "o conjunto de regras de conduta tiradas da disciplina interna da Administração".

O princípio da moralidade é de difícil tradução verbal, "talvez porque seja impossível enquadrar em um ou dois vocábulos a ampla gama de condutas e práticas desvirtuadoras das verdadeiras finalidades da Administração Pública” (MEDAUAR, 2015, p. 152).

Trata-se de princípio que exige a honestidade, lealdade, boafé no exercício da função administrativa, ou seja, a atuação não corrupta dos gestores públicos, ao tratar com a coisa de titularidade do Estado. Esta norma estabelece a obrigatoriedade de observância a padrões éticos de conduta, para que se assegure o exercício da função pública de forma a atender às necessidades coletivas (CARVALHO, 2017, p. 73).

Nesse contexto, a Constituição Federal de 1988, além de elencar a moralidade como um dos princípios da Administração Pública, também apresenta instrumentos para sancionar ou penalizar sua inobservância. 
Frustração ou Fraude à Licitação: Aspectos Penais e de...

A probidade, que há de caracterizar "a conduta e os atos das autoridades e agentes públicos, aparecendo como dever, decorre do princípio da moralidade administrativa”, equivalendo na linguagem comum à honestidade, honradez, integridade de caráter, retidão (MEDAUAR, 2015, p. 153).

O termo ímprobo deriva do latim probus e designa a pessoa devassa, desonesta ou corrupta. Em relação especificamente à esfera pública, é muito provável a presença de atributos negativos na condução dos negócios administrativos, caracterizando a improbidade como administrativa (SIMÃO, 2017, p. 49).

A prática de atos imorais, enquanto improbidade administrativa, acarreta ao responsável a aplicação de diversas sanções, como a suspensão dos direitos políticos e a perda da função pública. Nesse sentido, dispõe o $\S 4^{\circ}$ do art. 37 da Constituição Federal (BRASIL, 1988), que "os atos de improbidade administrativa importarão a suspensão dos direitos políticos, a perda da função pública, a indisponibilidade dos bens e o ressarcimento ao erário, na forma e gradação previstas em lei, sem prejuízo da ação penal cabível”.

Com a finalidade de regular o $\S 4^{\circ}$ do art. 37 da Carta Política de 1988, foi editada a Lei 8.429/92, conhecida como Lei de Improbidade Administrativa, inaugurando de forma não exaustiva um rol de atos de improbidade administrativa, bem como cominando e mensurando as respectivas sanções.

A Lei de Improbidade Administrativa, além de trazer em seu bojo as sanções aplicáveis aos agentes públicos ímprobos, categoriza os atos de improbidade administrativa, em rol meramente exemplificativo, em quatro grupos distintos: atos que importam em enriquecimento ilícito (art. $9^{\circ}$ ); atos que causam prejuízo ao erário (art. 10); atos decorrentes de concessão ou aplicação indevida de benefício financeiro ou tributário (art. 10-A); e atos que atentam contra os princípios da Administração Pública (art. 11).

Na ontologia jurídica a improbidade administrativa é um fato jurídico, e como tal reclama uma conduta humana positiva ou 
negativa, de efeitos jurídicos involuntários. Inserta na categoria das ilicitudes, sua prática, quando detectada, acarreta para seu autor sanções civis, administrativas e quase sempre criminais, posto tratarse de ilícito pluri-objetivo, quer dizer, agride de uma só vez diversos bens jurídicos tutelados pelo Direito Privado, pelo Direito Público e, dentro deste, pelo Direito Penal (PAZZAGLINI FILHO, ROSA; FAZZIO JÚNIOR, 1999, p. 40).

Desta forma, como requisito para a configuração de um ato de improbidade administrativa tem-se a necessidade da presença de um ato ilícito ou vedado pelo ordenamento jurídico. Em Direito Público, o princípio da legalidade ganha contornos próprios, apenas autorizando os agentes públicos a agirem segundo a lei (SIMÃO, 2017, p. 90). Entretanto, não basta que o ato se afigure meramente ilegal, devendo estar revestido de imoralidade ou desonestidade para caracterizar um ato de improbidade administrativa, ou seja, que se destinem a um desvio de finalidade ou abuso de poder.

Nos casos de corrupção, como são os atos de improbidade administrativa, a conduta do agente é dirigida a causar um resultado ilícito (enriquecimento ilícito; prejuízo ao erário; concessão ou aplicação indevida de benefício financeiro ou tributário; ou violação de princípios administrativos). $\mathrm{O}$ agente público não realiza um ato que lhe renda uma vantagem indevida, em benefício próprio ou de terceiros, acreditando ser ele lícito. Em outras palavras, se o agente público pratica um ato com a finalidade de beneficiar terceiro, assumindo com previsão o resultado, eis que afastada está a culpa (SIMÃO, 2017, p. 87). Por esta razão, apenas excepcionalmente se admite a punição do ato de improbidade administrativa com fundamento na culpa, e isso ocorre apenas nas hipóteses de prejuízo ao erário previstas no art. 10 da Lei 8.429/92, com a ressalva de que deve estar caracterizada a chamada culpa grave. 
Frustração ou Fraude à Licitação: Aspectos Penais e de...

2.2. ATOS LESIVOS AO ERÁRIO: ATOS QUE ACARRETAM FRUSTRAÇÃO DA LICITUDE DO PROCESSO LICITATÓRIO

O foco da pesquisa está restrito à frustração da licitude de processo licitatório prevista no inciso VIII do art. 10 da Lei 8.429/92 e no crime de frustração ou fraude à licitação contemplado no art. 90 da Lei 8.666/93, sendo imprescindível, assim, analisar a questão relativa ao prejuízo ao erário que implique em responsabilização pela prática de ato de improbidade administrativa.

A Seção II da Lei 8.429/92, na qual se insere o artigo 10, inciso VIII, em rol não exaustivo, mas meramente exemplificativo, trata dos atos de improbidade administrativa que causam prejuízo ao erário.

Nesse contexto, o Erário é a parcela do patrimônio público de conteúdo econômico-financeiro. Enquanto o conceito de patrimônio público é mais abrangente, pois compreende o complexo de bens e direitos públicos de valor econômico, artístico, estético, histórico e turístico, o Erário, como parte integrante do patrimônio público, limita-se aos bens e direitos de valor econômico, ou seja, aos recursos financeiros do Estado, ao Tesouro Público (PAZZAGLINI FILHO, 2015, p. 62).

As hipóteses previstas no art. 10 da Lei 8.429/92 exigem para a tipificação da improbidade administrativa os seguintes requisitos: conduta dolosa ou culposa do agente; conduta ilícita; existência de lesão ao erário ou perda patrimonial, desvio, apropriação, malbaratamento ou dilapidação dos bens ou haveres; não exigência de obtenção de vantagem patrimonial pelo agente; existência de nexo causal entre o exercício funcional e o prejuízo concreto gerado ao erário público (MORAES, 2002, p. 328-329).

No que se refere à conduta do agente, que pode ser comissiva ou omissiva, é imprescindível que esteja revestida de ilegalidade em sentido lato para ser possível a caracterização do ato de improbidade administrativa. Em outras palavras, a ação ou omissão funcional deve transgredir o conteúdo de uma norma por excesso de poder ou desvio 
de finalidade para que seja possível a responsabilização do agente por improbidade administrativa.

Com efeito, se o prejuízo ao erário for causado por conduta secundum legem, descabe falar em improbidade administrativa, nem tampouco em mera responsabilidade civil, que também tem por antecedente necessário uma ação ou omissão ilegítima (PAZZAGLINI FILHO, 2015, p. 63).

Corroborando referido entendimento, decidiu o Superior Tribunal de Justiça no julgamento do Agravo Regimental no Recurso Especial n. 1.065.588-SP (BRASIL, 2011) que:

\begin{abstract}
(...) é razoável presumir vício de conduta do agente público que pratica um ato contrário ao que foi recomendado pelos órgãos técnicos, por pareceres jurídicos ou pelo Tribunal de Contas. Mas não é razoável que se reconheça ou presuma esse vício justamente na conduta oposta: de ter agido segundo aquelas manifestações, ou de não ter promovido a revisão de atos praticados como nelas recomendado, ainda mais se não há dúvida quanto à lisura dos pareceres ou à idoneidade de quem os prolatou.
\end{abstract}

Também é preciso haver nexo causal entre esta conduta ímproba e o prejuízo advindo ao erário, pois, caso contrário, não haverá plausibilidade jurídica na imputação de responsabilidade, nem mesmo na esfera da responsabilidade objetiva.

Ainda, a doutrina e a jurisprudência são dominantes no sentido de se afigurar necessário que o tesouro público tenha sofrido dano material concreto para a caracterização do ato de improbidade administrativa previsto no art. 10 da Lei 8.249/92, não havendo que se falar em prejuízo presumido ou mero dano moral para tanto.

Nesse sentido, de acordo com Pedro da Silva Dinamarco (2001, p. 291):

[...] em toda a disciplina da nulidade dos atos jurídicos em geral (privados ou públicos), o prejuízo concreto é que justifica a anulação (pas de nulité sans grief). Daí o motivo para só caber a invalidação do ato ou o pedido de ressarcimento quando algum efetivo prejuízo existir. Se o ato se realizou e não 
causou prejuízo algum, ou se prejuízo algum foi provado (o que traz o mesmo resultado prático, pois quod non est in actis non est in mundo), a proclamação de eventual nulidade ou a procedência do pleito ressarcitório não tem lugar.

O Superior Tribunal de Justiça também acolheu o entendimento no sentido de que é necessária a existência de efetivo prejuízo para a caracterização de ato de improbidade administrativa, conforme se infere do julgamento do Agravo Regimental no Recurso Especial n. 1.129.636-RO (BRASIL, 2013):

\begin{abstract}
[...]
2. Este colendo Superior Tribunal de Justiça já decidiu, reiteradamente, que nos atos de improbidade administrativa descritos no art. 10 da Lei 8.429/92, é indispensável a demonstração de efetivo dano ao erário. Precedentes: REsp 1.233.502/MG, Rel. Min. CESAR ASFOR ROCHA, DJe 23.08.2012; REsp 1.206.741, Rel. Min. BENEDITO GONÇALVES, DJe 23.05.2012.
\end{abstract}

Contudo, embora não relacionado diretamente à hipótese de frustração da licitude de processo licitatório, objeto específico da presente pesquisa, necessário registrar a existência de posicionamento no âmbito do próprio Superior Tribunal de Justiça no sentido de que o simples fato de se dispensar licitação de forma ilícita por si só já representa prejuízo ao erário, independentemente da existência ou não de dano material.

Para a Corte, trata-se de hipótese de dano in re ipsa, ou seja, havendo dispensa ou inexigência ilegal de licitação, o prejuízo ao erário é presumido, independentemente de comprovação. Assim ao julgar questão relacionada à parte final do inciso VIII do art. 10 da Lei 8.429/92 (dispensa indevida do processo licitatório) no Recurso Especial n. 1.376.524-RJ, decidiu o Superior Tribunal de Justiça que (BRASIL, 2014):

É cabível a aplicação da pena de ressarcimento ao erário nos casos de ato de improbidade 
administrativa consistente na dispensa ilegal de procedimento licitatório (art. 10, VIII, da Lei 8.429/1992) mediante fracionamento indevido do objeto licitado. De fato, conforme entendimento jurisprudencial do STJ, a existência de prejuízo ao erário é condição para determinar o ressarcimento ao erário, nos moldes do art. 21, I, da Lei 8.429/1992 (REsp 1.214.605-SP, Segunda Turma, DJe 13/6/2013; e REsp 1.038.777-SP, Primeira Turma, DJe 16/3/2011). No caso, não há como concluir pela inexistência do dano, pois o prejuízo ao erário é inerente (in re ipsa) à conduta ímproba, na medida em que o Poder Público deixa de contratar a melhor proposta, por condutas de administradores. Precedentes citados: REsp 1.280.321-MG, Segunda Turma, DJe 9/3/2012; e REsp 817.921-SP, Segunda Turma, DJe 6/12/2012.

Importante destacar que, mesmo que tenha ocorrido a hipótese prevista no inciso VIII do art. 10 da Lei de Improbidade Administrativa, caso o agente tenha obtido vantagem patrimonial com o desvio de finalidade ou abuso de poder, a conduta passará a ser enquadrada no tipo insculpido no art. $9^{\circ}$ da Lei $8.429 / 92$, que prevê sanções ou penalidades mais severas.

Ainda, por guardar pertinência com o tema central da pesquisa, cumpre analisar o elemento subjetivo intrínseco à conduta do agente para caracterização do ato de improbidade administrativa que importe em prejuízo ao erário.

Com efeito, ao contrário das hipóteses que caracterizam atos de improbidade administrativa previstas nos artigos $9^{\circ}, 10-\mathrm{A}$ e 11, que necessariamente exigem a presença do elemento subjetivo dolo para sua configuração, as hipóteses contempladas no art. 10 da Lei 8.429/92 admitem tanto a modalidade dolosa quanto a culposa.

Em linhas gerais, "age dolosamente aquele que, diretamente, quer a produção do resultado, bem como aquele que, mesmo não o desejando de forma direta, assume o risco de produzi-lo" (GRECO, 2016, p. 289).

A improbidade administrativa dolosa, lesiva ao erário, acontece quando o autor do ato ilícito catalogado como ato ímprobo está consciente da antijuridicidade de sua ação ou omissão funcional 
Frustração ou Fraude à Licitação: Aspectos Penais e de...

e do resultado danoso que dela sobrevirá (PAZZAGLINI FILHO, 2015, p. 64).

Em relação à improbidade administrativa culposa, admitida tão somente na hipótese do art. 10 da Lei de Improbidade Administrativa, que também admite a modalidade dolosa, a questão afigura-se mais controversa.

Parcela da doutrina argumenta que a instituição legal da modalidade culposa da improbidade administrativa seria inconstitucional, uma vez que o aludido art. 10 da Lei 8.249/92 teria extrapolado os termos do art. $37, \S 4^{\circ}$, da Constituição Federal, para punir não apenas o agente desonesto, mas também o inábil (NEVES e OLIVEIRA, 2016, p. 85).

Nesse sentido, sustentam não ser possível enquadrar como improbidade administrativa um ato de agente público pelo simples fato de causar prejuízo ao erário, porquanto ato ímprobo não é sinônimo de ato danoso, até porque o agente público não realiza um ato que lhe renda uma vantagem indevida, em benefício próprio ou de terceiros, acreditando ser o ato lícito (SIMÃO, 2017, p. 88).

Ainda, conforme pontua Marcelo Figueiredo (2010, p. 96):

[...] em síntese, imaginemos dada omissão culposa (involuntária, portanto) do agente público causadora de pequena lesão ao erário. Para a lei, há ato de improbidade administrativa, e tollitur quaestio. Será crível afirmar-se que tal agente terá seus direitos políticos cassados por força de lei, perderá a função pública, terá seus bens indisponíveis etc. etc. etc. Parece que a conclusão do raciocínio aponta para o absurdo, indício de erro no percurso exegético. Enfim, é preciso abrandar o rigor legal, ou, por outra, amoldá-lo ao espírito constitucional.

Dessa forma, para a configuração da modalidade culposa da improbidade administrativa não basta a culpa simples, sendo necessária a culpa grave, caracterizada por expressiva e contundente inobservância do dever de cuidado objetivo pelo agente.

Referido entendimento prevalece na doutrina, ou seja, para que seja possível a responsabilização do agente nos termos do art. 10 
da Lei n. 8.249/92 por ação ou omissão culposa que resulte em prejuízo ao Erário, é imprescindível que esta culpa seja classificada como grave. A culpa grave, modalidade que mais se avizinha do dolo, é aquela decorrente de uma violação mais profunda ao dever de diligência que se exige do homem mediano (GONÇALVES, 2016, p. 491).

Na jurisprudência, da mesma forma, tem sido acolhida a tese da exigência de culpa grave para a caracterização da improbidade administrativa. A respeito, o Superior Tribunal de Justiça, ao julgar o Agravo Regimental no Agravo em Recurso Especial n. 494.124-RS, sufragou o entendimento no sentido de que a improbidade administrativa prevista no art. 10 da Lei 8.429/92 exige para sua configuração que a conduta seja dolosa ou pelo menos eivada de culpa grave (BRASIL, 2017).

Assim, a previsão da modalidade culposa como elemento anímico idôneo para caracterização dos atos de improbidade administrativa previstos no art. 10 da Lei 8.429/92 está sujeita a severas críticas tanto na doutrina como na jurisprudência.

Legalmente, não se nega que o inciso VIII do art. 10 da Lei 8.249/92 trata de atos de improbidade administrativa consubstanciados na frustração da licitude de processo licitatório ou de processo seletivo para celebração de parcerias com entidades sem fins lucrativos, ou ainda na dispensa indevida de licitação, que acarretem prejuízo ao erário, inclusive porque o agente público deverá realizar a licitação sempre que não se tratar dos casos expressamente previstos de dispensa ou inexigibilidade, e deverá, para tanto, observar todas as normas procedimentais necessárias à legitimidade do ato, por expressa previsão no inciso XXI do art. 37 da Constituição Federal e na Lei 8.666/93.

De igual forma, a ocorrência de qualquer tipo de fraude ou ilicitude no desenvolvimento do procedimento licitatório, desde sua inauguração até o encerramento, poderá acarretar ao agente público e a eventuais terceiros envolvidos, além da responsabilização por improbidade administrativa nos termos do inciso VIII do art. 10 da 
Frustração ou Fraude à Licitação: Aspectos Penais e de...

Lei 8.429/92, também a imputação do ilícito penal de frustração ou fraude à licitação prevista no art. 90 da 8.666/93.

\section{CRIME DE FRUSTRAÇÃO OU FRAUDE À LICITAÇÃO (ART. 9O DA LEI 8.666/93) E INTER-RELAÇÃO COM A IMPROBIDADE ADMINISTRATIVA}

A Constituição Federal de 1988 exige licitação para os contratos de obras, serviços, compras e alienações (art. 37, XXI), assim como para a concessão e a permissão de serviços públicos (art. 175). Por sua vez, a Lei 8.666/93, conforme disposto em seu artigo $1^{\circ}$, tem por objeto estabelecer normas gerais sobre licitações e contratos administrativos pertinentes a obras, serviços, inclusive de publicidade, compras, alienações e locações no âmbito dos Poderes da União, dos Estados, do Distrito Federal e dos Municípios.

No entanto, embora inegavelmente importante por possibilitar à Administração a escolha e a contratação da proposta mais vantajosa para atender aos interesses públicos ou coletivos, a Lei 8.666/93 possui textura aberta do termo normativo, estando, entre outros valores, atrelada à implementação do desenvolvimento sustentável, que deve inequivocamente se harmonizar com os demais objetivos da licitação (WACHELESKI; MEDEIROS; KOSCHINSKI, 2015, p. 14).

A licitação pode ser conceituada como o (MELLO, 2012, p. 534):

[...] procedimento administrativo pelo qual uma pessoa governamental, pretendendo alienar, adquirir ou locar bens, realizar obras ou serviços, outorgar concessões, permissões de obra, serviço ou de uso exclusivo de bem público, segundo condições 
por ela estipuladas previamente, convoca interessados na apresentação de propostas, a fim de selecionar a que se revele mais conveniente em função de parâmetros antecipadamente estabelecidos e divulgados.

A licitação busca a satisfação do interesse da coletividade, ao garantir contratos mais vantajosos à Administração, bem como garante a isonomia das contratações públicas. Portanto, a licitação tem um duplo objetivo: proporcionar ao poder público o negócio mais vantajoso e assegurar ao administrado a oportunidade de concorrer, em igualdade de condições, com os demais interessados (CARVALHO, 2017, p. 443).

A Administração Pública possui a árdua e complexa tarefa de manter o equilíbrio social e gerir a máquina pública, composta por infindáveis órgãos e agentes, razão pela qual não poderia a lei deixar ao critério do administrador a escolha das pessoas a serem contratas, porque essa liberdade daria margem a escolhas impróprias e escusas, desvirtuadas do interesse coletivo (CARVALHO, 2017, p. 441). A exigência legal de um procedimento licitatório objetiva superar esse risco, assegurando a supremacia e a indisponibilidade do interesse público.

A sociedade há muito tempo vinha exigindo uma legislação criminal que apenasse certos comportamentos havidos no mínimo como imorais, relacionados com as contratações celebradas pela Administração Pública (GASPARINI, 2004, p. 1). Antes da edição da Lei 8.666/93, somente seria possível a persecução penal de condutas que atingissem o erário público ou a moralidade administrativa se houvesse adequação às hipóteses limitadas encontradas no capítulo "Dos crimes contra a Administração Pública” do Código Penal, o que se apresentava totalmente insuficiente.

A Lei de Licitações trouxe ao ordenamento jurídico a tutela penal específica, ao prever condutas típicas próprias para aqueles que ofenderem a moralidade administrativa e outros bens jurídicos ligados diretamente à matéria licitatória, condutas típicas essas possíveis de serem aplicadas desde o início da licitação até a sua 
Frustração ou Fraude à Licitação: Aspectos Penais e de...

finalização, representando, assim, grande avanço na disciplina penal das contratações públicas (LEAL; RITT, 2014).

Bem jurídico, segundo Cláudio Heleno Fragoso (2003, p. 330), "é um bem protegido pelo direito; é, portanto, um valor da vida humana que o direito reconhece, e cuja preservação é regulada por uma norma jurídica".

A finalidade precípua do Direito Penal consiste em proteger os bens mais importantes e necessários para a própria sobrevivência da sociedade (GRECO, 2016, p. 2). No caso específico dos crimes licitatórios, segundo Cezar Roberto Bitencourt, é possível se identificar uma objetividade jurídica genérica, qual seja o escopo de preservar os princípios básicos da legalidade, da impessoalidade, da moralidade, da igualdade, da publicidade e da probidade administrativa (2012, p. 132).

$\mathrm{Na}$ tutela jurídico-penal das licitações implementada pela Lei 8.666/93 identifica-se um bem jurídico genérico protegido por todos os tipos penais, ou seja, um bem jurídico categorial que é a própria Administração Pública, e também bens jurídicos específicos ou em sentido técnico, protegidos por cada um dos tipos penais previstos na Lei de Lei de Licitações (PRADO; CASTRO, 2015).

O legislador, através dos tipos penais previstos nos artigos 89 a 98 da Lei de Licitações, objetiva salvaguardar o adequado funcionamento da Administração Pública, em especial por meio do respeito aos princípios que norteiam a atividade administrativa, como a legalidade, igualdade, a impessoalidade, a moralidade, a publicidade e a eficiência, bem como resguardas a lisura das licitações e contratações celebradas com o Poder Público.

Em resumo, o bem jurídico categorial objeto de tutela penal na Lei 8.666/93 é a Administração Pública, "no que tange ao regular (probo, correto e imparcial) funcionamento e disposição das contratações públicas, em que há exigência de procedimento licitatório, em observância aos preceitos (constitucionais e infraconstitucionais) que regem a atividade administrativa" (PRADO; CASTRO, 2015). 
O crime de fraude ao caráter competitivo do procedimento licitatório está previsto no art. 90 da Lei 8.666/93 nos seguintes termos: "frustrar ou fraudar, mediante ajuste, combinação ou qualquer outro expediente, o caráter competitivo do procedimento licitatório, com o intuito de obter, para si ou para outrem, vantagem decorrente da adjudicação do objeto da licitação".

Além da objetividade jurídica genérica dos crimes licitatórios, existe também uma multiplicidade de bens jurídicos tutelados pelo dispositivo legal em questão, destacando-se a proteção da competitividade do certame, a despeito da grande importância de tantos outros bens, como a própria transparência dos atos públicos e a probidade, moralidade e dignidade administrativa. A finalidade perquirida pela incriminação das condutas "frustrar" ou "fraudar" é inegavelmente garantir a concorrência legítima na competição licitatória (BITENCOURT, 2012, p. 184).

Trata-se de um tipo penal de ação múltipla ou conteúdo variado, o que significa dizer que mesmo que o agente pratique cumulativamente as condutas nucleares do tipo, "fraudar" ou "frustrar", responderá por um único delito.

A fraude e a frustração implicam necessariamente no engano ou erro do administrador público e dos demais concorrentes participantes do processo licitatório, visando a obtenção de alguma vantagem, normalmente econômica, mas não obrigatoriamente econômica (BITENCOURT, 2012, p. 191).

Havendo fraude ou frustração ao certame licitatório, em se tratando das consequências penais, parte da jurisprudência tem entendido ser prescindível a ocorrência de prejuízo, posto que ausente previsão legal como requisito para a materialização do delito, sendo que, na hipótese de efetiva ocorrência de dano ao erário, tal circunstância deverá ser valorada na dosagem da sanção atinente.

Nesse sentido, o Superior Tribunal de Justiça decidiu que o tipo penal insculpido no art. 90 da Lei de Licitações configura crime formal, pelo que não necessita de efetivo prejuízo para sua caracterização, conforme se verifica do julgamento do Agravo 
Frustração ou Fraude à Licitação: Aspectos Penais e de...

Regimental no Agravo em Recurso Especial n. 638.139-RS (BRASIL, 2016):

O entendimento desta Corte Superior de Justiça é no sentido de que o delito do art. 90 da Lei de Licitação prescinde da existência de dano ao erário, "haja vista que o dano se revela pela simples quebra do caráter competitivo entre os licitantes interessados em contratar, ocasionada com a frustração ou com a fraude no procedimento licitatório".

Por outro lado, ao julgar o Habeas Corpus n. 64.078-RJ, relacionado à prática do delito previsto no art. 90 da Lei 8.666/93, decidiu o Superior Tribunal de Justiça que "não é razoável, nem sequer lógica, a instauração de ação penal após a efetiva prestação de serviço que não trouxe nenhum prejuízo para a Administração, mormente quando se trata da modalidade de licitação que é o convite" (BRASIL, 2009a).

Da mesma forma, a Corte Especial, ao julgar a Ação Penal 330-SP, entendeu que as ações criminais "que envolvem o cometimento de crimes previstos na Lei de Licitações, exigem, para a configuração do delito, a evidenciação do dolo específico e do dano ao erário, para que consubstanciem a justa causa para a condenação penal" (BRASIL, 2008).

E, de acordo com o Tribunal Regional Federal da $4^{\text {a }}$ Região no julgamento da Apelação Criminal n. 2003.04.01.037292-2, "ausente a prova de obtenção de vantagem pecuniária em desfavor do município ou de que os réus tenham enriquecido ilicitamente às custas do erário, não se tipifica o crime de fraude à licitação" (BRASIL, 2009b).

No tocante ao elemento subjetivo da conduta, o ilícito penal tipificado no art. 90 da Lei 8.666/93 é punível apenas a título de dolo, posto que não existe previsão de punibilidade da modalidade culposa para o crime de frustração ou fraude à licitação. 
$\mathrm{Na}$ verdade, nenhuma das figuras típicas penais previstas na Lei 8.666/93 são puníveis a título de culpa, exigindo-se sempre o dolo do agente para sua configuração.

O dolo, in casu, corresponde à vontade livre e consciente de frustrar ou fraudar, por qualquer meio fraudulento, o caráter competitivo da licitação. Conforme preleciona Cezar Roberto Bitencourt (2012, p. 202), é necessário que o agente tenha consciência de que obtém uma vantagem decorrente da adjudicação do objeto da licitação, pois sem essa consciência ou sem a vantagem a conduta será atípica.

O Superior Tribunal de Justiça, por ocasião do julgamento da Ação Penal n. 590-ES (BRASIL, 2015), consignou ser imprescindível a demonstração do elemento subjetivo dolo para a caracterização do crime previsto no artigo 90 da Lei 8.666/93:

Para ser válida a peça de acusação com relação ao art. 90 da Lei das Licitações, mostra-se imperativo dissertar sobre todos os elementos da figura típica, indicando quem praticou o núcleo do tipo (frustrar ou fraudar), os meios empregados (ajuste, combinação ou qualquer outro expediente) e o especial fim de agir (obter para si ou para outrem vantagem decorrente da adjudicação do objeto da licitação), e ainda há que se demonstrar o vínculo da conduta do denunciado com seu interesse volitivo, bem como de que maneira, em que lugar, quando e com quem teria ajustado, combinado ou se associado para a consecução de seu objetivo.

O mesmo entendimento foi adotado pelo Tribunal de Justiça de Santa Catarina quando do julgamento da Apelação Criminal n. o008885-31.2011.8.24.0080 (SANTA CATARINA, 2017), nos seguintes termos:

É preciso mais do que mera presunção para se considerar prejudicado o caráter competitivo da licitação e é justamente nesse ponto que falhou a acusação ao não conseguir provas de que esse elemento normativo do tipo se configurou concretamente e não apenas de forma presumida. Para que houvesse efetiva ofensa à competitividade na licitação seria preciso, por exemplo, que fossem 
Frustração ou Fraude à Licitação: Aspectos Penais e de...

criadas facilidades para que os denunciados saíssem vencedores da licitação ou que fossem criados obstáculos aos demais participantes (...).

Portanto, para que possa restar configurado o tipo penal previsto no art. 90 da Lei 8.666/93, é indispensável que o agente tenha agido com dolo, não sendo suficiente para sua ocorrência eventual comportamento culposo do agente.

\section{CONCLUSÃo}

A pesquisa teve por objeto analisar as consequências políticoadministrativas e penais decorrentes de atos ilícitos que importem na frustação do caráter competitivo dos processos licitatórios, com ênfase no elemento subjetivo do ato de improbidade administrativa lesivo ao erário previsto no inciso VIII do artigo 10 da Lei 8.249/92 e do crime de frustração ou fraude à licitação contemplado no artigo 90 da Lei 8.666/93.

A regra básica para a contratação de obras, serviços, compras e alienações pela Administração Pública com terceiras pessoas é a obrigatoriedade de realização de prévio procedimento licitatório, nos termos do art. 37, inciso XXI, da Constituição Federal de 1988.

A licitação é o procedimento administrativo pelo qual a Administração Pública, respeitando o princípio da isonomia, contrata o negócio mais vantajoso de seu interesse, com terceiras pessoas, num universo o mais abrangente possível de interessados.

Por sua vez, a frustração e a fraude do procedimento licitatório são contrárias à essência constitucional da licitação, embora ambas sejam práticas corriqueiras no âmbito dos diversos entes da Administração Pública Brasileira. 
Normalmente, a fraude ou a frustração da licitação acarreta repercussões em várias órbitas do direito, especialmente na políticoadministrativa, como espécie de improbidade administrativa, e na penal, como espécie de crime de frustração ou fraude à licitação.

Sob a ótica político-administrativa, no que se refere ao ato de improbidade administrativa lesivo ao erário, inclusive os atos que frustrem a licitude do processo licitatório previstos no inciso VIII do art. 10 da Lei 8.249/92, é pacífico na doutrina e na jurisprudência sua configuração tanto a título de dolo como de culpa grave, diferentemente do que ocorre em relação aos atos de improbidade contemplados nos artigos $9^{\circ}$, 10-A e 11 da mesma lei, que obrigatoriamente exigem conduta dolosa para sua caracterização.

Para que reste caracterizado $o$ ato de improbidade administrativa nas hipóteses contempladas no art. 10 da Lei 8.429/92, inclusive em relação ao inciso VIII do referido artigo, parcela majoritária da doutrina e da jurisprudência entende ser imprescindível para sua configuração a existência de dano material concreto decorrente do ato.

Sob a ótica penal, a frustação ou fraude do caráter competitivo da licitação, tutelada pelo art. 90 da Lei 8.666/93, apenas autoriza a persecução penal na hipótese de dolo, ante a absoluta ausência de previsão legal no que se refere à modalidade culposa.

Ainda em relação ao crime previsto no art. 90 da Lei 8.666/93, inexiste uniformidade de pensamento na doutrina e na jurisprudência quanto à necessidade de demonstração do prejuízo concreto ao erário para sua caracterização, parte entendendo ser necessária, e parte sustentando ser dispensável a demonstração.

Assim, é possível afirmar que somente será possível a cumulação da improbidade administrativa prevista no inciso VIII do art. 10 da Lei de Improbidade Administrativa e do crime de frustração ou fraude do processo licitatório previsto no art. 90 da Lei 8.666/93, quando as duas hipóteses tiverem o dolo como elemento subjetivo e desde que nos dois casos se verifique prejuízo concreto ao erário. 
Frustração ou Fraude à Licitação: Aspectos Penais e de...

Tem-se, em conclusão, que restou demonstrada a hipótese inicial, no sentido de que, embora a frustração ou a fraude ao caráter competitivo da licitação ostente consequências tanto na seara político-administrativa quanto na esfera penal, não há uma correlação direta entre os atos ímprobos lesivos ao erário previstos no inciso VIII do art. 10 da Lei 8.429/92 e os crimes licitatórios contemplados no art. 90 da Lei 8.666/93, sendo que a incidência cumulativa de ambas as esferas está restrita à hipótese em que o ato ilícito esteja revestido pelo elemento subjetivo dolo e desde que no caso considerado exista prejuízo efetivo e concreto ao erário.

Data de Submissão: 08/04/2018

Data de Aprovação: 30/10/2018

Processo de Avaliação: double blind peer review

Editor Geral: Jailton Macena de Araújo

Editor de Área: Jailton Macena de Araújo

\section{REFERÊNCIAS}

BITENCOURT, Cezar Roberto. Direito penal das licitações. São Paulo: Saraiva, 2012.

BRASIL. Constituição da República Federativa do Brasil de 1988. Disponível em: 
<http://www.planalto.gov.br/ccivil_03/Constituicao/Constituicao.ht $\mathrm{m}>$. Acesso em: 12 out. 2017.

BRASIL. Lei 8.249, de 2 de junho de 1992. Disponível em: <http://www.planalto.gov.br/ccivil_o3/Leis/L8429.htm>. Acesso em: 12 out. 2017.

BRASIL. Lei 8.666, de 21 de junho de 1993. Disponível em: <http://www.planalto.gov.br/ccivil_03/Leis/L8429.htm>. Acesso em: 12 out. 2017.

BRASIL. Superior Tribunal de Justiça. Ação Penal n. 330-SP. Relator para o Acórdão Ministro Luiz Fux. Brasília: DJe, 15 dez. 2008. Disponível em:

<https://ww2.stj.jus.br/processo/revista/documento/mediado/?com ponente $=$ ITA\&sequencial $=726242 \&$ num_registro $=200400663784 \&$ data $=20081215 \&$ formato=PDF $>$. Acesso em: 7 jan. 2018.

BRASIL. Superior Tribunal de Justiça. Ação Penal n. 594-ES. Relator Ministro Jorge Mussi. Brasília: DJe 18 nov. 2015. Disponível em: $<$ http://www.stj.jus.br/SCON/jurisprudencia/doc.jsp?livre=fraude+l icita\%E7\%E3o+aus\%EAncia +dolo+9o\&b=ACOR\&p=true\&t=JURIDI CO\&l=10\&i=3>. Acesso em: 18 dez. 2017.

BRASIL. Superior Tribunal de Justiça. Agravo Regimental no Agravo em Recurso Especial n. 494.124-RS. Relatora Ministra Assusete Magalhães. Brasília: DJe, 9 maio 2017. Disponível em: <https://ww2.stj.jus.br/processo/revista/documento/mediado/?com ponente $=I T A \&$ sequencial $=1600478 \&$ num_registro $=201400689553$ \&data $=20170509 \&$ formato $=\mathrm{PDF}>$. Acesso em: 8 jan. 2018.

BRASIL. Superior Tribunal de Justiça. Agravo Regimental no Agravo em Recurso Especial n. 638.139-RS. Relator Ministro Reynaldo Soares da Fonseca. Brasília: DJe, 9 nov. 2016. Disponível em: <https://ww2.stj.jus.br/processo/revista/inteiroteor/?num_registro $=201500014254 \& d t \_$publicacao $=09 / 11 / 2016>$. Acesso em: 12 out. 2017.

BRASIL. Superior Tribunal de Justiça. Agravo Regimental no Recurso Especial n. 1.065.588-SP. Relator Ministro Hamilton Carvalhido. Brasília: DJe, 21 fev. 2011. Disponível em: <http://www.stj.jus.br/SCON/decisoes/doc.jsp?processo=1065588. NUM.\&b=DTXT\&p=true\&t=JURIDICO\&l=10\& $\mathrm{i}=2>$. Acesso em: 12 out. 2017.

BRASIL. Superior Tribunal de Justiça. Agravo Regimental no Recurso Especial n. 1.129.636-RO. Relator Ministro Napoleão Nunes Maia Filho. Brasília: DJe, 2 ago. 2013. Disponível em: <https://ww2.stj.jus.br/processo/revista/inteiroteor/?num_registro 
Frustração ou Fraude à Licitação: Aspectos Penais e de...

$=200801188295 \& d t \_$publicacao=21/02/2011 $>$. Acesso em: 12 out. 2017.

BRASIL. Superior Tribunal de Justiça. Habeas Corpus n. 64.078-RJ.

Relator Ministro Nilson Naves. Brasília, DJe, 30 nov. 2009a.

Disponível em:

<https://ww2.stj.jus.br/processo/revista/documento/mediado/?com ponente $=$ ITA\&sequencial $=916362 \&$ num_registro $=200601710330 \& d$ ata $=20091130 \&$ formato=PDF $>$. Acesso em: 7 jan. 2018.

BRASIL. Superior Tribunal de Justiça. Recurso Especial n. 1.376.524RJ. Relator Ministro Humberto Martins. Brasília: DJe, 8 set. 2014. Disponível em:

<https://ww2.stj.jus.br/processo/revista/inteiroteor/?num_registro $=201201104108 \& d t \_$publicacao $=09 / 09 / 2014>$. Acesso em: 12 out. 2017.

BRASIL. Tribunal Regional Federal da $4^{\mathrm{a}}$ Região. Apelação Criminal n. 2003.04.01.0372392-2. Relator Paulo Afonso Brum Vaz. Julgamento em 3 dez. 2009b.

BRITO, Débora. Lava Jato já gerou 120 condenações e mais de 1,2 mil anos de pena, diz balanço - 2016. Disponível em: $<$ http://agenciabrasil.ebc.com.br/politica/noticia/201612/procuradoria-do-parana-divulga-balanco-da-operacao-lava-jatoem-2016>. Acesso em: 20 out. 2018.

DINAMARCO, Pedro da Silva. Ação civil pública. São Paulo: Saraiva, 2001.

FIGUEIREDO, Marcelo. Probidade administrativa: comentários à lei 8.429/92 e legislação complementar. 6. ed. São Paulo: Malheiros, 2010.

FRAGOSO, Claudio Heleno. Lições de direito penal. 16. ed. Rio de Janeiro: Forense, 2003.

GRECO, Rogério. Curso de direito penal: parte geral. 18. ed. Rio de Janeiro: Impetus, 2016.

\section{HAURIOU, Maurice. Précis élémentaires de droit}

administratif. Paris: Recueil Sirey, 1926.

LEAL, Rogério Gesta; RITT, Caroline Fockink. Qual o bem jurídico penal protegido no âmbito dos crimes de licitações no sistema jurídico brasileiro? XI Seminário Internacional de Demandas Sociais e Políticas Públicas na Sociedade Contemporânea. VII Mostra de Trabalhos Jurídicos Científicos. Disponível em: $<$ http://online.unisc.br/acadnet/anais/index.php/sidspp/article/vie w/11722/1510>. Acesso em 8 abr. 2018. 
MEDAUAR, Odete. Direito administrativo moderno. 19. ed. São Paulo: Revista dos Tribunais, 2015.

MELLO, Celso Antônio Bandeira de. Curso de direito administrativo. São Paulo: Malheiros, 2012.

MORAES, Alexandre. Direito constitucional administrativo. São Paulo: Atlas, 2002.

NEVES, Daniel Amorim Assumpção; OLIVEIRA, Rafael Carvalho Rezende. Manual de improbidade administrativa. 4 ed. São Paulo: Método, 2016

PAZZAGLINI FILHO, Marino. Lei de improbidade administrativa comentada: aspectos constitucionais, administrativos, civis, criminais, processuais e de responsabilidade fiscal; legislação e jurisprudência atualizadas. 6. ed. São Paulo: Atlas, 2015 .

PAZZAGLINI FILHO, Marino; ROSA, Márcio Fernando Elias; FAZZIO Junior, Waldo. Improbidade administrativa: aspectos jurídicos da defesa do patrimônio público. 3. ed. São Paulo: Atlas, 1999.

PRADO, Luiz Regis; CASTRO, Bruna Azevedo de. Delito licitatório e bem jurídico-penal: algumas observações. Revista dos Tribunais, v. 957, jul. 2015. Disponível em: <

http://www.mpsp.mp.br/portal/page/portal/documentacao_e_divul gacao/doc_biblioteca/bibli_servicos_produtos/bibli_boletim/bibli_ bol_2006/RTrib_n.957.10.PDF >. Acesso: 8 abr. $201 \overline{8}$.

REMEDIO, José Antonio. Direito administrativo. 3. ed. São Paulo: Verbatim, 2018.

SANTA CATARINA. Tribunal de Justiça de Santa Catarina. Apelação Criminal n. o0o8885-31.2011.8.24.0080. Relator Desembargador Nelson Maia Peixoto. Julgamento em 16 nov. 2017.

SIMÃO, Calil. Improbidade administrativa: teoria e prática. 3. ed. Leme: J. H. Mizuno, 2017.

VEDOVATO, Luís Renato; LOPES, Thiago Henrique Teles. Uma visão crítica da posição do STJ sobre o periculum in mora presumido nas ações de improbidade para fins da decretação da indisponibilidade de bens. Revista da $A G U$, Brasília-DF, v. 16, n. 4, p. 273-292, out./dez. 2017. 
Frustração ou Fraude à Licitação: Aspectos Penais e de...

WACHELESKI, Marcelo Paulo; MEDEIROS, Clayton Gomes de; KOSCHINSKI, Patrícia de Souza Finamori. Contratações públicas como instrumento de efetivação do desenvolvimento sustentável. Prim@ Facie. João Pessoa, PPGCJ, v. 14, n. 26, p. 1-24, jan./jun. 2015. 


\title{
Bidding Fraud or Frustation: Criminal and Administrative Improbity Aspects
}

\author{
José Antonio Remedio
}

Luiz Felipe Gomes de Macedo Maganin

\begin{abstract}
The research aims to dispose about fraud to public licitation and administrative improbity. As a specific objective, the research seeks to analyze the criminal and political administrative consequences of acts that causes frustration or fraud of the legality of a bidding process, with emphasis in the subjective element of the improbity act provided for in item VIII of article 10 of Law 8.249/92 and of the bidding crime contemplated in article 90 of Law 8.666/93. The method is the deductive, based on legislation, doctrine and jurisprudence. The base rule for the hiring of third parties by public administration for buildings, services, purchases and disposals is the obligation of previous bidding procedure, in which the equality between the participants and the fairness of the contest are respected. Although the frustration or the fraud of the competitive bidding character has consequences both in the administrative and criminal courts, there is no direct correlation between acts of improbity harmful to the treasury and the crime of frustration or fraud to bid. It is also understood that the cumulative incidence in the political administrative and criminal domains is restricted to the case in which the illicit act is covered by the subjective criminal intent element and provided that there is concrete damage to the treasury in both hypothesis.
\end{abstract}

Keywords: Licitation Fraud. Licitation Frustration. Administrative Improbity. Fraudulent Licitation. Subjective Element. 